\title{
Assessment of camel and camel milk marketing practices in an emerging peri-urban production system in Isiolo County, Kenya
}

\author{
Issack Mohamed Noor ${ }^{1 *}$, Abdi Yakub Guliye ${ }^{1}$, Muhammad Tariq ${ }^{2,3}$ and Bockline Omedo Bebe ${ }^{1}$
}

\begin{abstract}
Pastoral camel management practices in Kenya, characterised by free herd mobility that enables efficient utilisation of rangeland resources, is progressively restricted to foraging within the vicinity of urban milk market outlets. The emerging peri-urban camel production system (PUCPS) has potential livelihood benefits to households, but adapting herd management practices responsive to market demands is a challenge with implications for its sustained development. This study assessed marketing practices in PUCPS, guided by two research questions. To what extent are (i) camel keepers involved in trading of camel stock and milk? (ii) milk hygiene practices responsive to market demands? Data was obtained from cross-sectional surveys complemented by focus group discussions. Compared to the pastoral production system, the peri-urban system exhibited greater market integration with more milk marketing opportunities, 2.4 times more ( $25.8 \%$ vs $62.8 \%)$ steer sales and 2.2 times more heifer purchases for breeding (12.3\% vs $27.5 \%$ ). Camels were sold to meet livelihood needs of the households as well as to raise cash for other direct investments. On the other hand, PUCPS growth is facing market barriers from poor milk hygiene practices. Compared to the pastoral system, the peri-urban system exhibits greater market-oriented production of camel stock and milk. Existing milk hygiene and quality practices are unlikely to meet the safety and quality requirements for urban consumers. Development of organised marketing channels and strengthening of processes that add value to milk would enable camel producers to earn more from their stock and guarantee safety and quality to urban consumers.
\end{abstract}

Keywords: Peri-urban camel production; Market integration; Camel milk; Milk hygiene; Value addition

\section{Background}

Camels are an important livelihood asset in the arid and semi-arid lands (ASALs) of Kenya which cover over $83 \%$ of the land mass and support about $30 \%$ (12 million) of the country's population. Camels are a source of food, cash income, transport means and have significant cultural functions to pastoral communities dominating in the ASALs (Guliye et al. 2007; MoLD 2007; Mehari et al. 2007a, b; Mahmoud 2010). These pastoral communities keep one humped camel (Camelus dromedarius), estimated at 2.97 million heads (KNBS 2010), and mainly concentrated in the ASALs. It is estimated that the Kenyan camel population is capable of producing between 340 and 350 million

\footnotetext{
* Correspondence: issacknoor@yahoo.com

${ }^{1}$ Department of Animal Science, Egerton University, P. O. Box 536-20115, Egerton, Kenya

Full list of author information is available at the end of the article
}

litres of milk (Faye 2007; Akweya et al. 2010a) and 10,000 tonnes of meat a year (Faye 2007). The health-promoting properties of camel milk are a strong boost for sales and, in certain regions such as the Middle East, are the drivers for intensification of camel dairying (Faye 2007).

In arid northern Kenya, camels are traditionally kept under pastoral (nomadic) production systems, characterised by low production inputs and herd/household mobility. This is a subsistence-based system utilising large mobile herds grazing on vast rangeland pasture resources. There is however a recent emergence of peri-urban camel production system (PUCPS) using milking herds grazed within proximity to urban market outlets for milk, meat and stock, where consumers and traders are members of pastoral communities (Matofari et al. 2007; Noor et al. 2012). Isiolo town in northern Kenya has a camel production system that exemplifies this emerging PUCPS, with the potential of adding value to camel milk and stock, which would improve 
livelihoods of the pastoral communities (LPP, LIFE Network, IUCN-WISP and FAO 2010) in the ASALs. Isiolo County has about 39,084 camels and a human population of about 143,294. (KNBS 2010).

The prevailing market-oriented camel production presents opportunities for poorer households to enhance their food and income securities (SRA 2004) in an area where annual income averages of US\$217 to 301 fall below the national average of US\$360 (ADF 2003). In these areas, viable alternative economic activities are lacking, resulting in a high dependency on famine relief support from government and non-governmental organisations (NGOs). Moreover, little is known about the marketing practices for camel livestock and milk in the emerging peri-urban system, which is an alternative income source. Such information would be useful for planning and implementation of targeted camel development programmes. This study was undertaken with the following objectives: (i) To estimate purchase and sale of camel stock and milk in the two systems and (ii) to determine whether milk hygiene practices in the peri-urban system are responsive to urban market requirement.

\section{Study area}

The study was conducted in Isiolo County, a typical ASAL area in northern Kenya with both peri-urban and pastoral camel production systems and a thriving camel milk trade (Figure 1). The study sites of peri-urban and pastoral areas were about $75 \mathrm{~km}$ from each other. Isiolo County is a semi-arid area that experiences recurring droughts with devastating losses of livestock and human lives. The rainfall pattern is bimodal but unpredictable and erratic in distribution. Long rains come in late March through May and short rains in November to December. Most parts of the County have mean annual temperatures between $24^{\circ} \mathrm{C}$ and $30^{\circ} \mathrm{C}$ (Herlocker et al. 1993). The Somali tribesmen, who speak Somali language,

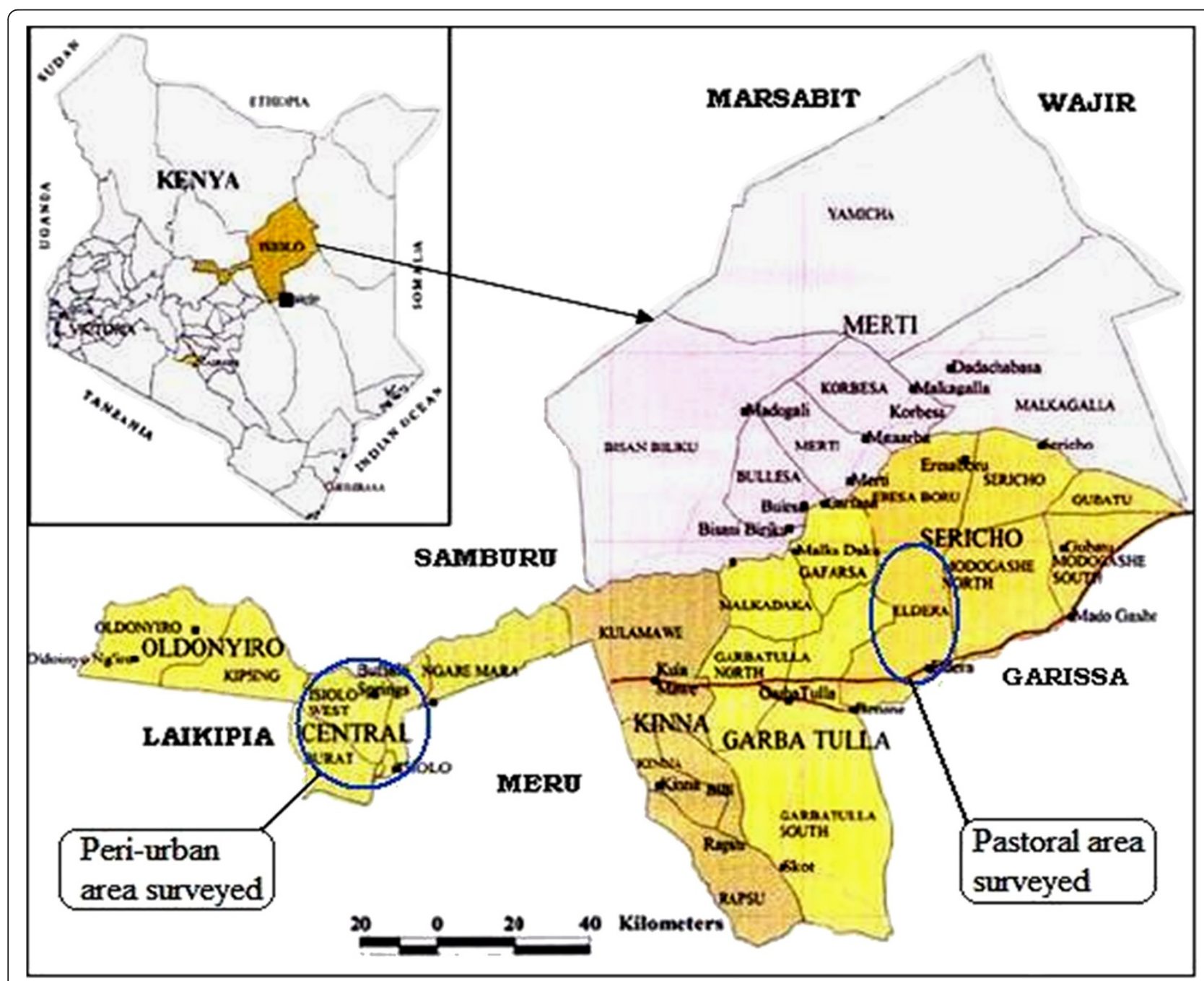

Figure 1 Map of Isiolo County (Kenya) showing the peri-urban and pastoral camel production study sites. 
form the predominant camel owners in both peri-urban $(80 \%)$ and pastoral $(90 \%)$ systems. The Borana tribesmen, who speak Boran language, were traditionally cattle keepers, until threats posed by recurrent prolonged drought spells in ASAL areas, awakened their interest in camel keeping. They form $18.3 \%$ of peri-urban camel owners but were yet to fully adopt a pastoral camel production system, with only $10 \%$ of Borana having adopted.

\section{Methods}

\section{Data collection}

Two cross-sectional surveys were conducted in February 2007: one within the peri-urban area of Isiolo town and the other in the pastoral rangelands of the County where the pastoral camel production system is practised and where traditional attachments to socio-cultural roles of camels remain strong. The former represented a periurban camel production system, where milking herds are reared within the vicinity of Isiolo town with a lot of market integration through sale of camel stock and camel milk. The latter area represents traditional camel production in a pastoral setting, where pastoralists rear their camels in the rangelands for subsistence and they move with their herds in search of pasture, water and mineral licks.

Because of high mobility, the scattered nature of pastoral camel herds and the necessity to obtain consent of the herd owners in accessing their herds, sampling in both rangelands and peri-urban sites was limited to accessible herds whose owners were willing to participate in the studies. The sampling included 70 pastoral herds and 60 peri-urban herds. The individual herds formed the sampling units, and the herd owners interviewed provided the primary data. Trained enumerators, who spoke the language of the respondents and were supervised by the authors, conducted the surveys using a questionnaire pre-tested on a small sample (10 respondents) of camel herders to test the clarity of the questions. Data collected through the surveys was a recall of the last 12 months preceding the interview period and was complemented by a focus group discussion (FGD) involving 50 participants. The participants included camel producers (22), camel milk traders (10), representatives of government departments (10), non-governmental organizations (NGOs) (2), community-based organisations (2) and local leaders (4). Camel producers and traders were the majority (70\%) of the FGD participants. Specifically, data was collected on sales and purchases of camel stock and milk. Camel stocks were in four classes of heifers (before age at first calving), steers (up to 4 years of age), breeding females and breeding males. Prices and reasons for selling and buying were obtained for each case. Data on milk hygiene and marketing channels was collected during herd visits and FGD with stakeholders.

\section{Data analyses}

Comparative descriptive and inferential statistical analyses of pastoral and peri-urban camel systems were done to test for any statistically significant difference in means of the test parameters. In this regard, camel stock purchases and sales were computed as a proportion of purchases and sales divided by the average number in the herd for each class during the year preceding the survey. The Chi-square test was applied to detect any significant differences in means between pastoral and peri-urban systems and Fisher's exact test used where $50 \%$ of the cells had expected counts less than 5 . The proportion of animals sold and purchased was the proxy for the extent of market orientation. Frequencies for different reasons for sale declared for each animal sold within each system were calculated as a percentage of the number of responses. The average price of camel stock sale and purchase was computed for each class and subjected to a $t$ test to detect significant differences between the systems.

\section{Results}

\section{Marketing of camel stock}

The estimates of camel stock sales and purchases in the studied pastoral and peri-urban systems are presented in Table 1. Compared to pastoral producers, peri-urban producers sold 2.4 times more steer surplus stock $(25.8 \%$ vs $62.8 \%$ ) and bought 2.2 times more heifer breeding stock $(12.3 \%$ vs $27.5 \%)$. Although the difference in the

Table 1 Sales and purchases of different camel classes by camel keepers in pastoral and peri-urban systems

\begin{tabular}{|c|c|c|c|c|}
\hline Camel class & $\begin{array}{l}\text { Production } \\
\text { system }\end{array}$ & $N$ (camels) & Sales (\%) & Purchases (\%) \\
\hline \multirow[t]{4}{*}{ Heifers } & Pastoral & 301 & 5.3 & 12.3 \\
\hline & Peri-urban & 382 & 2.1 & 27.5 \\
\hline & Total & 683 & 3.5 & 20.8 \\
\hline & $x^{2}$ value & & $5.153^{*}$ & $23.602^{* *}$ \\
\hline \multirow[t]{4}{*}{ Steers ( $\leq 4$ years) } & Pastoral & 186 & 25.8 & 2.7 \\
\hline & Peri-urban & 204 & 62.8 & 0.7 \\
\hline & Total & 390 & 45.1 & 1.8 \\
\hline & $x^{2}$ value & & $53.610^{* *}$ & 1.610 NS \\
\hline \multirow[t]{4}{*}{ Breeding females } & Pastoral & 1,143 & 2.6 & 0.3 \\
\hline & Peri-urban & 1,217 & 1.5 & 0.5 \\
\hline & Total & 2,360 & 2.0 & 0.4 \\
\hline & $x 2$ value & & $3.882^{*}$ & 0.825 NS \\
\hline \multirow[t]{4}{*}{ Breeding males } & Pastoral & 156 & 29.5 & 1.9 \\
\hline & Peri-urban & 82 & 17.1 & 0.0 \\
\hline & Total & 238 & 25.2 & 1.3 \\
\hline & x2 value & & $4.393^{*}$ & 1.597 NS \\
\hline
\end{tabular}

${ }^{*}=p<0.05 ;{ }^{* *}=p<0.0001 ; \mathrm{NS}=p>0.05$. 
means of breeding female and male camel sales was significantly higher $(p<0.05)$ in pastoral than in peri-urban system, the actual numbers involved were low. Further, there was minimal buying of the two camel classes into their respective herds; the reasons being that selling of breeding animals were usually considered suspicious in one way or another. Unless under exceptional circumstances, adult breeding females brought to market were considered as being culled for reason(s) known to the owner. Though buyers interested in meat animals have no problem so long as the body condition was good, animal breeders interested in replacement stock would have a second thought before purchasing an adult breeding female from the market.

The stated reasons for selling different classes of camels are presented in Table 2. In both systems, camels were sold mainly for livelihood needs of the households (food, clothing, healthcare, school fees) and to raise cash for direct investments, and were rarely sold because of disease, poor performance or destocking. This scenario was reflected both in overall sales of camel stock and for the different camel classes. It was only in respect of breeding females in both systems and breeding males in the pastoral system where sales attributed to poor performance gains some prominence. The main reason for buying camels was for breeding purposes.

Tables 3 and 4 present the mean prices (given in Kenya shillings and equivalent US dollars) for selling and purchasing different classes of camels in pastoral and peri-urban systems. The mean prices were significantly higher $(p<0.05)$ for both sales and purchases in the pastoral system than in peri-urban system. This finding may be attributed to the fact that the quality/weight of peri-urban camels sold was lower than pastoral camels which are better fed as a result of better exploitation of wider rangeland resources.

\section{Marketing of camel milk}

Under the pastoral system, milk production was mainly for subsistence (household) consumption and calf feeding. Discussions with pastoral producers revealed that they would wish to sell milk to get money for other needs, but they do not have ease of access to markets due to distance and the poor road infrastructure. Figure 2 illustrates camel milk marketing channels from producers to consumers in Nairobi urban market. The bulk of the milk was sourced from peri-urban herds and less from pastoral herds located in areas near to reliable road network to Isiolo town (such as Kulamawe in Kinna Division and Boji in Garba Tulla Division) (Figure 2). The bulk of the camel milk leaving Isiolo town for Nairobi urban markets was fresh raw milk. Neither the producers nor the traders were value adding.

Analyses of the marketing characteristics of camel milk from Isiolo peri-urban area revealed a litre of fresh raw camel milk was sold at about Ksh. 30 (equivalent to US\$0.4). This was about eight times lower than the price of processed milk sold at Ksh. 240 (equivalent to US\$3.5) in Nairobi urban markets. Processed camel milk sells for a lot more than unprocessed milk due to the improved hygienic quality. In Nairobi, processed camel milk is usually sold at up-market outlets to consumers who value hygienic quality and are also ready to pay more for the better quality. Milk from within the peri-urban area was transported over a distance of about $10 \mathrm{~km}$ to reach Isiolo town market using donkeys (94.9\%), although a few producers (5.1\%) with large volumes of milk use four-wheel pick-up vehicles. The milk buyers/purchasers (100\%) were milk traders (Figure 2), and most $(71.2 \%)$ of them buy milk on informal contractual arrangements with producers, reflecting an organised marketing structure.

Table 2 Frequently mentioned reason(s) for selling different camel classes in pastoral and peri-urban systems

\begin{tabular}{|c|c|c|c|c|c|c|c|}
\hline \multirow[t]{2}{*}{ Camel class } & \multirow{2}{*}{$\begin{array}{l}\text { Production } \\
\text { system }\end{array}$} & \multirow{2}{*}{$\begin{array}{c}\text { Total } \\
\text { sales }(N)\end{array}$} & \multicolumn{5}{|c|}{ Reasons for selling (\%) } \\
\hline & & & Livelihood needs & Direct investments & Disease cases & Poor performance & Destocking \\
\hline \multirow[t]{2}{*}{ Overall } & Pastoral & 140 & 65.0 & 26.4 & 0.7 & 7.1 & 0.7 \\
\hline & Peri-urban & 168 & 67.9 & 22.0 & 1.8 & 6.0 & 2.4 \\
\hline \multirow[t]{2}{*}{ Heifers } & Pastoral & 16 & 8.6 & 2.9 & 0.0 & 0.0 & 0.0 \\
\hline & Peri-urban & 8 & 4.2 & 0.0 & 0.6 & 0.0 & 0.0 \\
\hline \multirow[t]{2}{*}{ Steers ( $\leq 4$ years) } & Pastoral & 48 & 26.4 & 7.9 & 0.0 & 0.0 & 0.0 \\
\hline & Peri-urban & 128 & 60.1 & 16.1 & 0.0 & 0.0 & 0.0 \\
\hline \multirow[t]{2}{*}{ Breeding females } & Pastoral & 30 & 9.3 & 7.1 & 0.7 & 4.3 & 0.0 \\
\hline & Peri-urban & 18 & 0.6 & 3.0 & 1.2 & 6.0 & 0.0 \\
\hline \multirow[t]{2}{*}{ Breeding males } & Pastoral & 46 & 20.7 & 8.6 & 0.0 & 2.9 & 0.7 \\
\hline & Peri-urban & 14 & 3.0 & 3.0 & 0.0 & 0.0 & 2.4 \\
\hline
\end{tabular}


Table 3 Mean ( \pm SD) sale price (Ksh) of different classes of camels in pastoral and peri-urban systems

\begin{tabular}{lcccc}
\hline Camel class & \multicolumn{2}{c}{ Production system } & Mean difference & $\boldsymbol{t}$ test ( $\boldsymbol{p}$ value) \\
\cline { 2 - 3 } & Pastoral & Peri-urban & & $0.282 \mathrm{NS}$ \\
\hline Heifers & $17,070 \pm 10,864$ & $11,200 \pm 5,575$ & 338 & $0.835 \mathrm{NS}$ \\
Steers ( $\leq 4$ years) & $11,138 \pm 7,838$ & $10,800 \pm 3,082$ & 2,838 & $0.407 \mathrm{NS}$ \\
Breeding females & $16,738 \pm 10,322$ & $13,900 \pm 3,814$ & 7,352 & $0.044^{*}$ \\
Breeding males & $20,152 \pm 8,148$ & $12,800 \pm 4,532$ & \\
\hline
\end{tabular}

KSh. $69=$ US\$1 at the time of the study (2007). ${ }^{*} p<0.05 ; \mathrm{NS}=p>0.05$.

\section{Milk hygiene and quality testing}

Participants in the FGD identified the main challenges in achieving clean milk production and marketing as (i) insufficient water availability during the camel milking process, (ii) milk contamination arising from saliva of the calf during suckling to initiate milk letdown prior to milking and (iii) use of plastic containers for milking, storage and transportation that are generally not easy to clean and therefore cause milk spoilage, despite washing with hot water. The use of overnight milk cooling facilities was limited to a few camel keepers who were able to transport evening milk to Isiolo town where such facilities were available. Different types of milk quality testing methods were used by producers and traders in Isiolo County. The results show most producers and milk traders in both systems $(85.7 \%$ for pastoral and $100 \%$ for peri-urban system) use subjective assessments of taste and sight (colour of milk) for hygiene and quality indicators.

\section{Discussion}

\section{Marketing of camel stock and milk}

The study provides evidence of greater trading of camel stock and milk in peri-urban system than in pastoral system, reflecting a shift towards a market-oriented production objective. The Kenya Camel Association (KCA 2009) reported camel prices in Kenya ranged between Ksh. 17,000 and Ksh. 35,000 (equivalent to between US\$246 and US\$507). The price depended on a number of factors, including age, sex, body condition and market supply and demand forces (KCA 2009). In agreement with the present findings, Mahmoud (2010) reported a vibrant and lucrative camel stock market in the northern Kenya border town of Moyale. Farah et al. (2004a) have associated observed attractive prices and incentives with pastoral household participation in the market economy. Information on camel meat consumption was not collected in this study, but camel slaughter is on daily basis in the urban centres of Kenya, indicating an increase in camel trading, and most of the slaughter was steer surplus stock and unproductive females. Sale of camel stock enables pastoral households to meet livelihood needs and raise cash for other direct investments. Similar findings were reported by Mehari et al. (2007a) for camel pastoralists in the Somali region of Ethiopia. A possible explanation for the significantly higher $(p<0.05)$ mean prices (Tables 3 and 4) for both sales and purchases of camel stock in pastoral than in peri-urban system could be due to lack of adequate market information. Since pastoral producers were usually far from urban markets, coupled with the possible challenges associated with recall data, the prices quoted most probably reflect optimism.

Some authors (Chabari and Njiru 1991; Noor 1999) have reported a number of impediments to livestock marketing in the ASALs of northern Kenya including poor quality roads, lack of reliable market information, stock rustling and general insecurity, absence of consistent livestock marketing policies and hence dependency on private traders. Strengthening processes that add value to the products (LPP, LIFE Network, IUCN-WISP and FAO 2010) would be ideal interventions to enable camel producers in peri-urban systems to earn more from their stock. However, due to poor infrastructure in remote rangelands, conventional value addition processes (such as butter and cheese) are not feasible in most pastoral systems. Traditionally, camel milk is consumed either fresh or in the form of fermented milk, known as susa among the Somali pastoralists. It has been observed (Noor et al. 2012) that fermented camel milk is sometimes sold at almost half the price of fresh

Table 4 Mean ( \pm SD) purchase price (Ksh) of different classes of camels in pastoral and peri-urban systems

\begin{tabular}{lllll}
\hline Camel class & \multicolumn{2}{c}{ Production system } & Mean difference & \multirow{2}{t}{ test ( $\boldsymbol{p}$ value) } \\
\cline { 2 - 3 } & Pastoral & Peri-urban & & $0.013^{*}$ \\
\hline Heifers & $22,308 \pm 16,616$ & $13,022 \pm 3,294$ & 9,286 & $0.833 \mathrm{NS}$ \\
Steers ( $\leq 4$ years) & $9,375 \pm 2,428$ & $10,000^{\mathrm{a}}$ & 625 & $0.797 \mathrm{NS}$ \\
Breeding females & $15,000 \pm 1,000$ & $14,000 \pm 6,164$ & 1,000 & \\
\hline
\end{tabular}

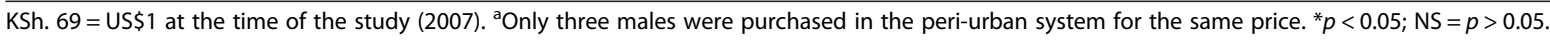




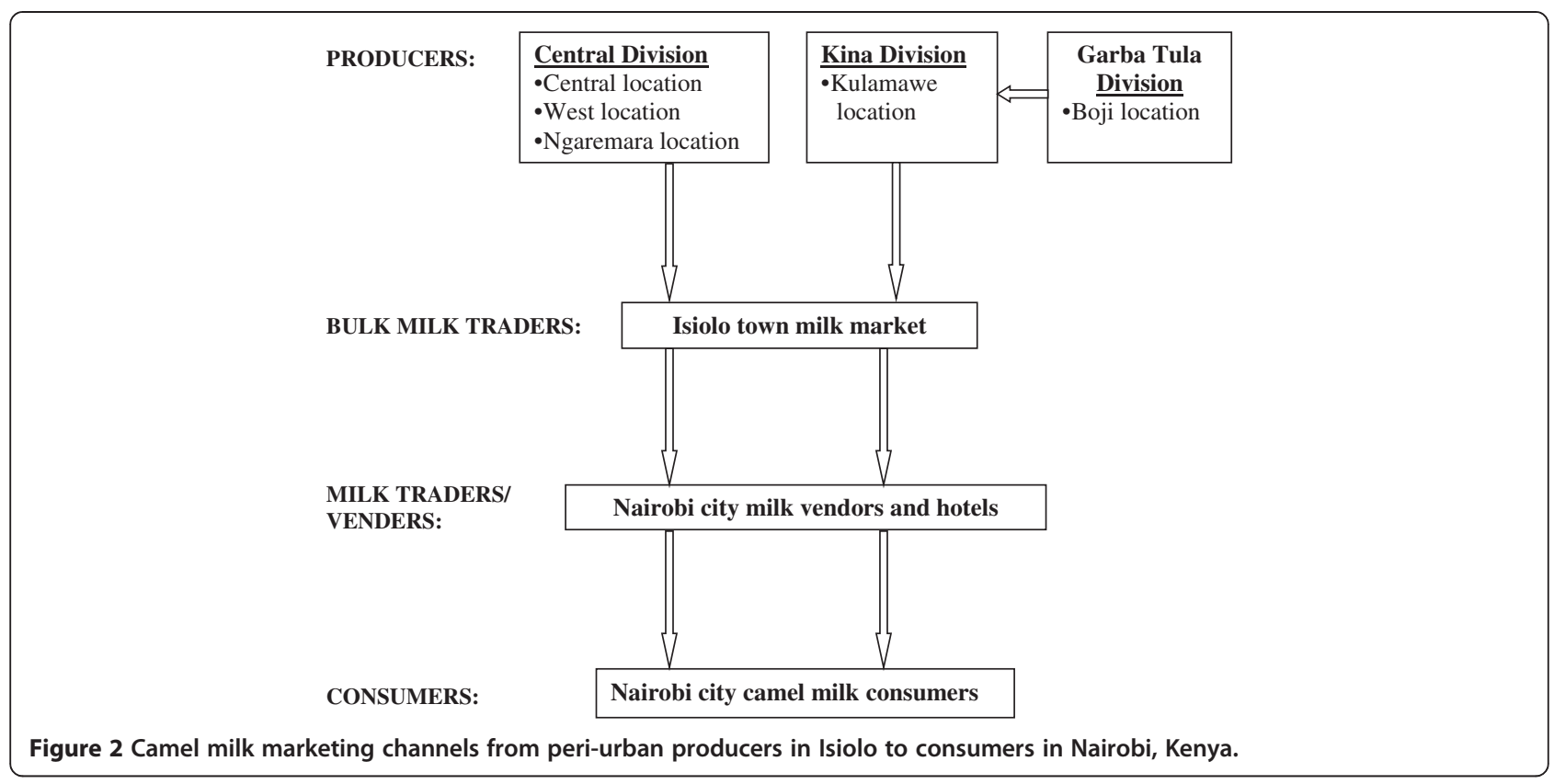

milk and therefore does not bring as much income as fresh milk. According to Farah et al. (2007), the manufacture of butter and cheese from camel milk is not a tradition in most of the pastoral societies in eastern Africa. These products were normally obtained from cow, goat and sheep milk.

The increase in commercialization of camel milk in urban niche markets observed in Kenya in the present study, was similar to trends reported in neighbouring countries like Somalia (Herren 1990; Farah et al. 2007) and Ethiopia (Seifu 2007; Mahmoud 2010) as well as in other African countries such as Djibouti, Mauritania, Morocco and Sudan (Abeiderrahmane 2013). In the PUCPS of Isiolo town, the sale of camel milk was found to be an important economic activity, attributable to the prospect of better returns arising from the increasing demand for camel milk in urban markets. The price of camel milk in Isiolo town of US\$0.4 per litre was similar to the US $\$ 0.34$ per litre reported by Baars (2000) for producers in neighbouring eastern Ethiopia. However, the price of milk seems not to be influenced by the distance between the production area and terminal market.

\section{Milk hygiene and quality testing}

This study provides evidence that hygiene and quality practices are unlikely to meet the safety and quality requirements for urban consumers. Subjective assessment of safety and quality based on colour and taste still predominate. These are inadequate for addressing hygiene issues previously observed in camel milking and milk handling. Several authors (Farah et al. 2004b; Matofari et al. 2007, 2013) have identified poor hygiene of the commercialised milk. Most camel milk traders buy only fresh milk from producers since most camel milk consumers prefer fresh unfermented milk. In particular, a major segment of the consumers, comprising the Somali community, believe unprocessed camel milk has medicinal properties which would otherwise be lost through heating. However, Akweya et al. (2010b) observed that camels are usually milked in poor sanitary conditions, with all the predisposing factors to diseases such as mastitis that include dust, flies and scarce water resources. In particular, lack of clean water for milking, lack of understanding of the principles of clean milk production by camel keepers and lack of overnight milk cooling facilities present challenges. Other studies (Akweya et al. 2010b; Meile 2010; Wanjohi et al. 2010) have also demonstrated the presence of common milk pathogens, mostly Staphylococcus aureus, in camel milk. Farah et al. (2004b) also reported drinking untreated camel milk could cause gastric distress and more serious zoonotic diseases such as brucellosis, tuberculosis or typhoid. Consequently, there could be health risks associated with the consumption of raw camel milk, which could limit wider marketing opportunities, particularly amongst non-traditional camel keeping communities.

\section{Conclusions}

Compared to the pastoral camel production system, PUCPS exhibits greater market-oriented production of camel stock and milk, but this requires improved hygiene practices to guarantee safety and quality to urban consumers and achieve a better price for producers.

Given these prevailing conditions of peri-urban camel production, development agencies interested in supporting livelihoods of rural communities using the camel as 
a potential resource, could assist in overcoming challenges to marketing of camel milk through replacement of plastic with quality steel or aluminium containers for storage and transporting of milk, improved water supply sources within camel-keeping areas, raising awareness of camel herders about clean milking and handling practice and through establishment of overnight milk cooling facilities within production areas. Appropriate value addition to camel milk would potentially enhance household income for peri-urban camel producers. Development of organised marketing channels can facilitate adoption of hygiene practices. Development agencies need to consider supporting the establishment of milk processing plant at Isiolo to pasteurise and add value to the growing niche urban town markets in Kenya. Besides, the use of such appropriate technologies will reduce postproduction losses, remove market barriers related to quality and safety standards and expand market access, thereby opening up more business and job opportunities for peri-urban camel producers.

\section{Competing interests}

The authors declare that they have no competing interests.

\section{Authors' contributions}

The work reported in this manuscript was a component of a wider Doctorate study for IMN. AYG and BOB were the University supervisors of the candidate, while the MT is a visiting professor from the University of Kassel, Germany and a specialist in peri-urban livestock production systems. IMN, AYG and BOB made substantial contributions to the work from conception through data collection, analysis, drafting and revising the manuscript. MT participated in drafting and revision of the manuscript. All authors read and approved the final manuscript.

\section{Authors' information}

IMN was a Ph.D. student and is now a livestock production systems analyst at the Department of Animal Science, Egerton University, Njoro, Kenya. AYG is a ruminant nutritionist at the Department of Animal Science, Egerton University, Njoro, Kenya. MT is a peri-urban livestock production systems specialist at University of Kassel, Witzenhausen, Germany and University of Agriculture, Faisalabad, Pakistan. BOB is a livestock production systems specialist at the Department of Animal Science, Egerton University, Njoro, Kenya.

\section{Acknowledgements}

The authors acknowledge the research grant for the project entitled Enhancing Camel Productivity for Food Security and Wealth Creation for the Peri-Urban Camel Producers in Isiolo, Northern Kenya from the Kenya Government's Commission for Higher Education. Further, we acknowledge additional funding from Egerton University, Kenya Muslims Charitable Society and field logistical support from Ewaso Ng'iro North Development Authority with headquarters in Isiolo town. Sincere appreciation also goes to the camel herders in Isiolo County for their time during interviews and focus group discussions. Permission to acknowledge has been obtained from the institutions mentioned.

\section{Author details}

'Department of Animal Science, Egerton University, P. O. Box 536-20115, Egerton, Kenya. ${ }^{2}$ Animal Husbandry in the Tropics and Subtropics, University of Kassel, D-37213, Witzenhausen, Germany. ${ }^{3}$ Department of Livestock Management, University of Agriculture Faisalabad, Faisalabad 38000, Pakistan.

Received: 5 September 2013 Accepted: 4 November 2013 Published: 02 Dec 2013

\section{References}

Abeiderrahmane, NJ. 2013. Camel cheese - seemed like a good idea. CreateSpace Independent Publishing Platform. http://www.amazon.co.uk/Camel-CheeseSeemed. Accessed 13 November 2013.

ADF (African Development Fund). 2003. Kenya ASAL-based livestock and rural livelihoods support project: Appraisal report. Nairobi: Ministry of Livestock Development archives.

Akweya, BA, CG Gitao, and MW Okoth. 2010a. The acceptability of camel milk and milk products from North Eastern Province in some urban areas of Kenya. Garissa: A poster presented at International Camel Symposium.

Akweya, BA, CG Gitao, and MW Okoth. 2010b. The prevalence of common milk pathogens and antibiotic resistance of the organisms in camel milk from North Eastern Province of Kenya. Garissa: A paper presented at International Camel Symposium

Baars, RMT. 2000. Costs and returns of camels, cattle and small ruminants in pastoral herds in eastern Ethiopia. Tropical Animal Health and Production 32: 113-126.

Chabari, FN, and GK Njiru. 1991. Livestock marketing. In Marsabit District range management handbook of Kenya. vol. II, I, ed. HJ Schwartz, S Shabani, and D Walther. Nairobi: Ministry of Livestock Development 111-129.

Farah, KO, DM Nyariki, RK Ngugi, IM Noor, and AY Guliye. 2004a. The Somali and the camel: Ecology, management and economics. Anthropologist 6(1): 45-55.

Farah, Z, S Kappeler, A Bruntse, and L Mertz. 2004b. Milk products. In Milk and meat from the camel: Handbook on products and processing, ed. Z Farah and A Fischer, 29-50. Zurich: vdf Hochschulverlag AG an der ETH Zurich.

Farah, Z, M Mollet, M Younan, and R Dahi. 2007. Camel dairy in Somalia: Limiting factors and development potential. Livestock Science 110: 187-191.

Faye, B. 2007. Focus on camels. http://www.new-ag.info/en/focus/focusltem.php? $a=1273$. Accessed 13 November 2013.

Guliye, AY, IM Noor, BO Bebe, and IS Koskey. 2007. Role of camels (Camelus dromedarius) in the traditional lifestyle of Somali pastoralists in northern Kenya. Outlook on Agriculture 36(1): 29-34.

Herlocker, DJ, SB Shaaban, and S Wilkes. 1993. Range management handbook of Kenya. volume II, 5: Isiolo District. Nairobi: Ministry of Agriculture, Livestock Development and Marketing.

Herren, UJ. 1990. The commercial sale of camel milk from pastoral herds in the Mogadishu Hinterlands, Somalia. Paper no. 30. London: Pastoral Development Network ODI.

KCA. 2009. Kenya Camel Association (KCA) annual report. Nairobi: KCA.

KNBS (Kenya National Bureau of Statistics). 2010. 2009 Population and housing census. Nairobi: Ministry of Finance and Planning

LPP, LIFE Network, IUCN-WISP and FAO. 2010. Adding value to livestock diversity: Marketing to promote local breeds and improve livelihoods. Paper no. 168. Rome: FAO Animal Production and Health.

Mahmoud, HA. 2010. Camel marketing in the Northern Kenya/Southern Ethiopia Borderlands. FAC Research Update 003. Brighton: Future Agricultures Consortium, University of Sussex.

Matofari, JW, A Shitandi, PL Shalo, NJ Nanua, and M Younan. 2007. A survey of Salmonella enterica contamination of camel milk in Kenya. African Journal of Microbiology Research 1(4): 46-50.

Matofari, JW, PL Shalo, M Younan, NJ Nanua, A Adongo, A Qabale, and BN Misiko. 2013. Analysis of microbial quality and safety of camel (Camelus dromedarius) milk chain and implications in Kenya. Journal of Agricultural Extension and Rural Development 5(3): 50-54. http://academicjournals.org/ JAERD. Accessed 29 April 2013.

Mehari, Y, Z Mekuriaw, and G Gebru. 2007a. Camel and camel product marketing in Babilie and Kebribeyah woredas of the Jijiga Zone, Somali Region, Ethiopia. Livestock Research for Rural Development 19(49). http://Irrd.cipav. org.co/index.html. Accessed 1 May 2007.

Mehari, Y, Z Mekuriaw, and G Gebru. 2007b. Potentials of camel production in Babilie and Kebribeyah woredas of the Jijiga Zone, Somali Region, Ethiopia. Livestock Research for Rural Development 19(58). http://lrrd.cipav.org.co/ index.html. Accessed 1 May 2007.

Meile, L. 2010. Microbial biodiversity of camel milk and fermented camel milk products: Technology, hygiene and safety. Garissa: A paper presented at International Camel Symposium.

MoLD. 2007. Ministry of Livestock Development (MoLD) annual report. Nairobi: MoLD. Noor, IM. 1999. A description of the pastoral camel production system in Moyale District, Kenya, MSc Thesis. University of Nairobi. 
Noor, IM, BO Bebe, and AY Guliye. 2012. Analysis of an emerging peri-urban camel production in Isiolo County, Northern Kenya. Journal of Camelid Science 2012(5): 41-61.

Seifu, E. 2007. Handling, preservation and utilization of camel milk and camel milk products in Shinile and Jijiga Zones, eastern Ethiopia. Livestock Research for Rural Development 19(86). http:///rrd.cipav.org.co/index.html. Accessed 8 Dec 2009.

SRA. 2004. Strategy for revitalizing agriculture (SRA). Ministry of Agriculture and Ministry of Livestock and Fisheries Development, Republic of Kenya, Government Printer. Nairobi: Ministry of Livestock Development archives.

Wanjohi, GM, CG Gitao, and LC Bebora. 2010. The hygienic quality of camel milk marketed from North Eastern Province of Kenya and how it can be improved. Garissa: A paper presented at International Camel Symposium.

\subsection{6/2041-7136-3-28}

Cite this article as: Noor et al: Assessment of camel and camel milk marketing practices in an emerging peri-urban production system in Isiolo County, Kenya. Pastoralism: Research, Policy and Practice 2013, 3:28

\section{Submit your manuscript to a SpringerOpen ${ }^{\circ}$ journal and benefit from:}

- Convenient online submission

- Rigorous peer review

- Immediate publication on acceptance

- Open access: articles freely available online

- High visibility within the field

- Retaining the copyright to your article 